\title{
Multispecies probiotics applications through feed addition on cultured tilapia to prevent streptococcosis
}

\section{Aplikasi probiotik multispesies melalui pakan pada budidaya ikan nila Oreochromis niloticus untuk pencegahan streptococcosis}

\author{
Nurin Dalilah Ayu Destianingrum¹, Munti Yuhana ${ }^{1 *}$, Angela Mariana Lusiastuti² \\ ${ }^{1}$ Department of Aquaculture, Faculty of Fisheries and Marine Science, Bogor Agricultural University \\ Campus IPB Dramaga Bogor, West Java, Indonesia 16680 \\ ${ }^{2}$ Center for Research and Development of Freshwater Aquaculture, Jl. Sempur No.1, Bogor, West Java, Indonesia \\ *E-mail: myhn@gmx.ch
}

\begin{abstract}
Streptococcosis is one of the diseases that often arise and can cause death by $100 \%$ in tilapia fish farming. This study aimed to determine the most optimal probiotics combination of cells Bacillus cereus P22, Bacillus subtillis ND2 and Staphylococcus lentus L1k through the feed for streptococcosis prevention. The experimental fish with initial body weight of $(13.06 \pm 0.18 \mathrm{~g})$, were randomly distributed at 25 fish per $60 \mathrm{~L}$ water, and reared for 21 days. The fish fed with supplemented feed (except controls) with FR 3\%, about three times a day, for 14 days. The treatment of combination probiotics-supplemented feed on, K1 (P22 and ND2, density of $10^{6} \mathrm{CFU} / \mathrm{mL}$ ), K2 (ND2 and L1k, density of $10^{5} \mathrm{CFU} / \mathrm{mL}$ ), K3 (P22 and L1k, density of $10^{5} \mathrm{CFU} / \mathrm{mL}$ ), K4 (P22, ND2 and L1k, density of $10^{6} \mathrm{CFU} / \mathrm{mL}$ ), the negative and positive control treatment given feed without supplementation. On day 15, the experimental fish, (except negative control) were challenged with Streptococcus agalactiae via intraperitoneal injection $0.1 \mathrm{~mL} /$ fish $\left(10^{4} \mathrm{CFU} / \mathrm{mL}\right)$. The results indicated that the best combination was shown by K3 (the combination of Bacillus cereus P22 and Staphylococcus lentus L1k) with cells addition 1\% (v/w). The result of K3 survival rate shown $89.33 \pm 6.11 \%$, significantly different from the $\mathrm{K}+$ and $\mathrm{K}$ - wich were $66.67 \pm 4.62 \%$ and $88.00 \pm 8.00 \%$. The highest increased immune value shown by K3 were wich phagocytic index value $64.00 \pm 2.65 \%$ and respiratory burst activity value $0.07 \pm 0.00 \mathrm{OD}$.
\end{abstract}

Keywords: multispecies probiotics, Oreochormis niloticus, streptococcosis

\begin{abstract}
ABSTRAK
Streptococcosis merupakan salah satu penyakit yang seringkali muncul dan dapat menyebabkan kematian hingga $100 \%$ pada budidaya ikan nila. Penelitian ini bertujuan untuk menentukan kombinasi optimal dari probiotik Bacillus cereus P22, Bacillus subtillis ND2, dan Staphylococcus lentus L1k melalui pakan sebagai upaya pencegahan streptococcosis. Ikan uji berukuran $(13,06 \pm 0,18 \mathrm{~g})$, secara acak dipelihara dengan kepadatan 25 ekor/ akuarium dengan volume air $60 \mathrm{~L}$, dipelihara selama 21 hari dan diberi pakan yang disuplementasi probiotik (kecuali kontrol) dengan perkiraan FR 3\% sebanyak tiga kali sehari, selama 14 hari. Perlakuan kombinasi probiotik yang disuplementasi pada pakan yaitu: K1 (P22 dan ND2, kepadatan $10^{6} \mathrm{CFU} / \mathrm{mL}$ ), K2 (ND2 dan L1k, kepadatan $10^{5} \mathrm{CFU} / \mathrm{mL}$ ), K3 (P22 dan L1k, kepadatan $\left.10^{5} \mathrm{CFU} / \mathrm{mL}\right), \mathrm{K} 4$ (P22, ND2 dan L1k, kepadatan $\left.10^{6} \mathrm{CFU} / \mathrm{mL}\right)$, perlakuan kontrol negatif dan posistif diberi pakan tanpa suplementasi probiotik. Pada hari ke-15, ikan uji (kecuali kontrol negatif) diinjeksi dengan Streptococcus agalactiae dengan kepadatan $10^{4} \mathrm{CFU} / \mathrm{mL}$ sebanyak $0,1 \mathrm{~mL}$ secara intraperitoneal. Hasil penelitian ini menunjukkan bahwa kombinasi probiotik multispesies terbaik adalah perlakuan K3 (kombinasi Bacillus cereus P22 dan Staphylococcus lentus L1k) dengan dosis 1\% ( $(\mathrm{v} / \mathrm{w})$. Nilai kelangsungan hidup K3 didapat $89,33 \pm 6,11 \%$, berbeda nyata dengan $\mathrm{K}+(66,67 \pm 4,62 \%)$ dan $\mathrm{K}-(88,00 \pm 8,00 \%)$. Nilai respons imun dengan peningkatan tertinggi pada perlakuan K3 dengan nilai indeks fagositik $64,00 \pm 2,65 \%$ dan aktivitas respiratory burst $0,07 \pm 0,00 \mathrm{OD}$.
\end{abstract}

Kata kunci: probiotik multispesies, Oreochormis niloticus, streptococcosis 


\section{INTRODUCTION}

Streptococcosis is a disease that often arises in Tilapia farming activities and is caused by a pathogen called Streptococcus agalactiae (Taukhid et al., 2014). S. agalactiae pathogen attacks are acute in tilapia (Hernandez et al., 2009). The outbreaks of $S$. agalactiae infection were first noticed in Malaysian (Nijah et al. 2012), Asian and Pacific Asian waters. In 2008, streptococcosis was reported to cause tremendous economic losses, which reached approximately $\$ 250$ million (Klesius et al., 2008). In addition, a case of streptococcosis infection in Karawang (West Java) resulted in mortality rates of up to $50 \%$ on tilapia farms (Gardenia et al., 2011). Visual clinical symptoms of $S$. agalactiae infection included detaching scale and abnormal swimming motions (Ye et al., 2011), bulging eyes (exophthalmos) (Filho et al., 2009), bulged stomach and bleeding on the body. Changes in the anatomy of internal organs that can occur are liver dysfunction, swelling spleen, and brain dysfunction (Hardi et al., 2011; Li et al., 2014).

Probiotic is defined as living microorganisms that once provided in sufficient amount, can positively affect the microbiota balance of the intestine, leading to increment in the functions of the host immune system (Sanders, 2008). The application of probiotics is an attempt in preventing the infection of cultured fish by disease (Flores, 2011). Widyaningsih (2011), stated that probiotics positively influence the immune system. Two main techniques have been used in the application of probiotics i.e. through the rearing medium or the feed. Several types of research have proved that probiotic application can benefit tilapia farming by increasing immune system and resistance against diseases (Aly et al., 2008a), so as to increase the survival rate of the fish (Aly et al., 2008b). According to Sya'bani et al. (2015), the supplementation of Bacillus sp. and Staphylococcus lentus (every 2 days) at a dose of $10^{3} \mathrm{CFU} / \mathrm{mL}$ through the rearing medium of catfish can result in a survival rate of $93.33 \%$. Meanwhile, results of Bacillus sp. probiotic application, at a dose of $10^{6} \mathrm{CFU} / \mathrm{mL}$, through the rearing medium could maintain a survival rate of $100 \%$ in common carp (Haditomo et al., 2016). According to Fidyandini et al. (2016), application of multispecies Bacillus subtilis and Staphylococcus lentus probiotic through rearing medium of catfish (Dumbo strain) can not only push Aeromonas hydrophila cell population up to $40 \%$ compared to the positive control, but also increase survival rate, growth, immune response, and decrease feed conversion ratio as well.

In accordance with the descriptions above, a solution that has been applied to the problem of $S$. agalactiae pathogen infection on the potential of optimal intensive production of tilapia is probiotics. The present research was carried out to determine the best combination of multispecies probiotics that can be supplemented through the feed to prevent streptococcosis.

\section{MATERIALS AND METHODS}

\section{Test fish}

The test fish used in the present study was BEST (Bogor Enhanced Strain tilapia) tilapia Oreochormis niloticus. The fish had an average body length of $9.10 \pm 0.08 \mathrm{~cm}$ with an average body weight of $13.06 \pm 0.18 \mathrm{~g}$ and were brought from Plasma Nutfah Research Installation, the center for freshwater research and development, Cijeruk, West Java. Fish were acclimatized in fiber tanks that were equipped with an aeration system and fed three times a day at satiation.

\section{Pathogenic and probiotic bacteria preparation}

The bacterium used in the present study was Streptococcus agalactiae N14G pathogen, while probiotic bacteria used included Bacillus cereus P22, Bacillus subtilis ND2, and Staphylococcus lentus L1k. N14G, P22, and ND2 isolates were part of collections from the center for research and development of freshwater aquaculture. L1k isolate was a collection from fish health laboratory, at the Faculty of Fisheries and Marine Science, Bogor Agricultural University.

Antibiotic resistance marker was used on isolates that were to be used in the present study in order to determine the presence of the bacterium in the rearing environment, which presence could be monitored with total plate count (TPC) method. Antibiotic used in the present study was Rifampicin (Rif) as S. agalactiae N14G marker. $S$. agalactiae $\mathrm{N} 14 \mathrm{G}$ inoculant was cultured in 10 $\mathrm{mL}$ BHIB (brain heart infusion broth), incubated for 48 hours at a temperature of $28{ }^{\circ} \mathrm{C}$, recultured in $10 \mathrm{~mL}$ BHIB containing $100 \mu \mathrm{g} / \mathrm{mL}$ of Rifampicin (Rif), and finally incubated for 48 hours. The N14G Rif ${ }^{\mathrm{R}}$ that grew was inoculated on BHIA (brain heart infusion agar) containing the same dose of antibiotics.

An antibiotic that was used as resistance marker for probiotic bacteria was based on Fidyandini 
et al. (2016) research i.e. ciprofloxacin (Cip) as P22 marker, cefadroxil (Cef) as ND2 marker, tetrasiklin (Tet) as L1k marker with an antibiotic dose of $100 \mu \mathrm{g} / \mathrm{mL}$. Antibiotic resistance marking process was carried out by culturing each isolate on TSB (tryptic soy broth) medium and incubating for 24 hours at a temperature of $28{ }^{\circ} \mathrm{C}$. Each grown isolate was re-cultured on TSB containing $100 \mu \mathrm{g} / \mathrm{mL}$ of antibiotic and incubated for 24 hours at $28^{\circ} \mathrm{C}$. Resistant isolates that have grown were re-cultured each on TSA (tryptic soy agar) medium containing the same dose of antibiotic and measurements of overflow in pathogenic and probiotic isolates were carried out through spread method (Madigan et al., 2011).

\section{Test feed preparation}

Commercial feed (FF 999) with a protein content of $38 \%$ was used in the present study. The prepared probiotics combinations that were supplemented in the feed were as follows: K1 (probiotic combination of P22 $\mathrm{Cip}^{\mathrm{R}} 10^{6} \mathrm{CFU} /$ $\mathrm{mL}$ and ND2 $\mathrm{Cef}^{\mathrm{R}} 10^{6} \mathrm{CFU} / \mathrm{mL}$ ), K2 (probiotic combination of ND2 $\mathrm{Cef}^{\mathrm{R}} 10^{5} \mathrm{CFU} / \mathrm{mL}$ and $\mathrm{L} 1 \mathrm{k}$ $\operatorname{Tet}^{\mathrm{R}} 10^{5} \mathrm{CFU} / \mathrm{mL}$ ), K3 (probiotic combination of P22 $\mathrm{Cip}^{\mathrm{R}} 10^{5} \mathrm{CFU} / \mathrm{mL}$ and $\mathrm{L} 1 \mathrm{k} \mathrm{Tet}{ }^{\mathrm{R}} 10^{5} \mathrm{CFU} /$ $\mathrm{mL}$ ), K4 (probiotic combination of $\mathrm{P} 22 \mathrm{Cip}^{\mathrm{R}} 10^{6}$ $\mathrm{CFU} / \mathrm{mL}, \mathrm{ND} 2 \mathrm{Cef}^{\mathrm{R}} 10^{6} \mathrm{CFU} / \mathrm{mL}$ and $\mathrm{L} 1 \mathrm{k} \mathrm{Tet}{ }^{\mathrm{R}} 10^{6}$ $\mathrm{CFU} / \mathrm{mL}$ ), meanwhile $\mathrm{K}+$ (positive control) and $\mathrm{K}$ (negative control) were not supplemented with probiotic combinations. The process of pellet formulation included mixing multispecies probiotics, at a dose of $1 \%(\mathrm{v} / \mathrm{b})$ (Setiawati et al., 2013), and white egg, $2 \%(\mathrm{v} / \mathrm{b})$, which was added with a $6 \%(\mathrm{v} / \mathrm{b})$ distilled water. Afterward, the solution was homogenized, evenly mixed with the feed, and dried.

\section{Fish rearing}

Rearing facilities used in the present study were 24 aquariums $\left(65 \times 35 \times 35 \mathrm{~cm}^{3}\right)$ with a capacity of 60 Liters of water each. The stocking density of test fish was 25 fish/aquarium. Fish were fed on a $38 \%$ protein feed and daily feeding rate (FR) was maintained at $3 \%$ of the test fish biomass. Feeding was performed three times a day while feeding with probiotic supplemented feed was performed once a day (in the morning) for 14 days.

Water quality in the rearing facility was maintained at an optimum level by mean of discharging and water exchange (50\%) every two days. Water quality parameters such as dissolved oxygen, $\mathrm{pH}$, and ammonia were measured throughout the research. Meanwhile, water temperature was daily measured. The ranges of water quality parameters during the present research were as follows: DO (3.9-5.2 mg/L), $\mathrm{pH}$ (6.3-7.5) and ammonia (0.001-0.0147 $\mathrm{mg} / \mathrm{L})$, while water temperature ranged between 27 and $29{ }^{\circ} \mathrm{C}$. The ranges of water quality parameters in the present study were in line with the standard ranges for tilapia culture as described by the national standards (SNI 7550: 2009 (2009).

\section{Challenge test}

Tilapia that were given treatments for 14 days were injected (intraperitoneal) with $S$. agalactiae pathogenic bacteria on day 15 (Positive control, $\mathrm{K} 1, \mathrm{~K} 2, \mathrm{~K} 3$, and $\mathrm{K} 4$ ) with at a concentration of $10^{4} \mathrm{CFU} / \mathrm{mL}$ and a dose of $0.1 \mathrm{~mL} / \mathrm{fish}$. Fish in the negative treatment were injected with PBS at $0.1 \mathrm{~mL} /$ fish and mortality was observed over a period of 7 days.

\section{Test parameters}

The test parameters were as follows: growth performances such survival rate (SR) (Effendi, 2002), specific growth rate (SGR) (Huisman, 1987), feed conversion ratio (FCR) (Takeuchi, 1988), that were measured throughout the research. The immune response was observed by mean of collecting blood samples from 3 fish in each treatment. Blood samples were collected on day $0,7,14$ (pre-challenge test), day 17, 19 (post challenge test), until the end of the research period on day 21. The immune response involved parameters such as phagocytic activity (PA) (Anderson \& siwicki, 1995), and respiratory burst (RB) based on Secombes (1990) method that was modified according to Stasiack and Baumann (1996) in Singh et al. (2013). Monitoring of pathogenic cell population was performed on day 17, 19, and 21. Monitoring of probiotic cell population was performed on day $3,6,9,12,15$, 18, and 21. Monitoring of both pathogenic and probiotic cell population was performed through Cawan sebar method (Madigan et al., 2012).

\section{Data analysis}

A completely randomized design with 6 treatments was used in this study and each treatment was replicated 4 times. Data on SR, SGR, FCR, PA, RB, were analyzed using ANOVA test (on SPSS ver. 20) at an interval of $P<0.05$. An ANOVA test was followed by Duncan's post-hoc comparison test if significant differences were found. Monitoring of pathogenic and probiotic bacteria abundance was descriptively analyzed. 


\section{RESULTS AND DISCUSSION}

\section{Results}

Survival rate and growth performance

K3 treatment had the highest survival rate $(89.33 \pm 6.11 \%)$ which was significantly different $(\mathrm{P}<0.05)$ compared to treatment $\mathrm{K}+$ $(66.67 \pm 4.62 \%)$. In addition, K3 treatment had the highest SGR $(2.37 \pm 0.02 \%)$ as well that significantly differed to other treatments (including control). The lowest FCR was observed in K3 treatment $(1.26 \pm 0.03 \%)$, but was not significantly different to $\mathrm{K} 1$ treatment $(1.30 \pm 0.03 \%)$. However, the FCR of the two mentioned treatments were significantly different $(\mathrm{P}<0.05)$ to those of control, K2 (1.32 $\pm 0.03 \%), \mathrm{K} 4(1.36 \pm 0.04 \%)$, which were in turn significantly different to control (Table 1).

\section{Phagocytic activity (PA)}

The observation of the phagocytic activity (PA) in the test fish blood (in each sampling) resulted in fluctuating outcomes. The highest PA activity was observed in treatment K3 during the rearing period and significantly differed to $(\mathrm{P}<0.05$, Figure 1) both other treatments and control.

\section{Respiratory burst activity (RB)}

The respiratory burst activity after 14 days of probiotics supplementation resulted in significant differences among treatments and control $(\mathrm{P}<0.05)$. The highest respiratory burst was shown in treatment $\mathrm{K} 3$ which was significantly different to other treatment and control $(\mathrm{P}<0.05$, Figure 2$)$ during the 21 days rearing period.

\section{Monitoring of pathogenic and probiotic cells population}

S. agalactiae $\mathrm{N} 14 \mathrm{G} \mathrm{Rif}^{\mathrm{R}}$ observation results on the brain (Figure 3A), the eyes (Figure 3B) and the kidney (Figure 3C) of the test fish showed that the fish in each treatment, that was supplemented with multispecies probiotics, was able to significantly press the growth of $S$. agalactiae $\mathrm{N} 14 \mathrm{G}$ Rif $^{\mathrm{R}}$ $(\mathrm{P}<0.05)$ compared to control. Treatment K3 had the best results in terms of multispecies probiotic combination (P22 Cip ${ }^{\mathrm{R}}$ and $\left.\mathrm{L} 1 \mathrm{k} \mathrm{Tet}{ }^{\mathrm{R}}\right)$.

The results of the total probiotic cells observation during the rearing period in the intestine of the test fish (Figure 4A) showed fluctuation between probiotic treatments $(\mathrm{K} 1, \mathrm{~K} 2$, $\mathrm{K} 3$, and $\mathrm{K} 4$ ), however, all the probiotic treatments experienced significant increments.

\section{Discussion}

The results of the present study on tilapia fed on treatments K1, K2, K3, and K4 showed positive responses, leading to survival rates that were not significantly different among the four probiotic treatments. However, the survival of the probiotic treatments were significantly different $(\mathrm{P}<0.05$; Table 1) compared to that of treatment $\mathrm{K}+$, indicating that supplementation of probiotics through feed can increase the immune response, leading to an increase in survival. Nevertheless, the highest survival was observed in treatment $\mathrm{K} 3$ $(89.33 \%)$. It was believed that the K3 probiotic combination treatment $\left(\mathrm{P} 22 \mathrm{Cip}^{\mathrm{R}}\right.$ and $\left.\mathrm{L} 1 \mathrm{k} \mathrm{Tet}{ }^{\mathrm{R}}\right)$, with a dose of $1 \%$ and a concentration of $10^{5} \mathrm{CFU} /$ $\mathrm{mL}$, was able not only of expanding the immune response, but also providing a better pressing against the growth of $S$. agalactiae N14G Rif ${ }^{\mathrm{R}}$ pathogen. Indeed, the results of monitoring the abundance of pathogens in targeted organs of the test fish with $S$. agalactiae N14G Rif ${ }^{\mathrm{R}}$ pathogenic bacteria demonstrated that treatment K3 had the lowest pathogen abundance (Figure 3). According to Haditomo et al. (2016), the supplementation of Bacillus sp. probiotic through the rearing medium can maintain the survival of common carp at 100\%. In addition, Wang et al. (2016) stated that supplementing Bacillus cereus through both medium and feed can improve the health status of the fish. However, supplementation through feed

Table 1. Survival rate (SR), specific growth rate (SGR) and feed conversion ratio (FCR)

\begin{tabular}{ccccccc}
\hline \multirow{2}{*}{ Parameters } & \multicolumn{6}{c}{ Treatments } \\
\cline { 2 - 7 } & $\mathrm{K}-$ & $\mathrm{K}+$ & $\mathrm{K} 1$ & $\mathrm{~K} 2$ & $\mathrm{~K} 3$ & $\mathrm{~K} 4$ \\
\hline SR $(\%)$ & $88.00 \pm 8.00 \mathrm{~b}$ & $66.67 \pm 4.62 \mathrm{a}$ & $86.67 \pm 6.11 \mathrm{~b}$ & $88.00 \pm 8.00 \mathrm{~b}$ & $89.33 \pm 6.11 \mathrm{~b}$ & $85.33 \pm 8.33 \mathrm{~b}$ \\
SGR (\%/day) & $2.04 \pm 0.04 \mathrm{~b}$ & $1.85 \pm 0.04 \mathrm{a}$ & $2.31 \pm 0.03 \mathrm{~d}$ & $2.24 \pm 0.02 \mathrm{c}$ & $2.37 \pm 0.02 \mathrm{e}$ & $2.22 \pm 0.02 \mathrm{c}$ \\
FCR (\%) & $1.45 \pm 0.05 \mathrm{~d}$ & $1.59 \pm 0.02 \mathrm{e}$ & $1.30 \pm 0.03 \mathrm{ab}$ & $1.32 \pm 0.03 \mathrm{~b}$ & $1.26 \pm 0.03 \mathrm{a}$ & $1.36 \pm 0.04 \mathrm{cb}$ \\
\hline
\end{tabular}

Note: Negative control (K-), Positive control (K+), P22 CipR and ND2 CefR combination (K1), ND2 CefR (K2) and L1k TetR combination (K2), P22 CipR and L1k TetR combination (K3) and P22 CipR, ND2 CefR and L1k TetR combination (K4). Data on the same line with different letters showed significant differences among treatments $(\mathrm{P}<0.05)$. 
is a more effective way in improving the immune system of tilapia.

The application of probiotic combination in the four treatments, as observed on the growth response of the test fish, showed significant differences in terms of growth rate among probiotic treatments $(\mathrm{P}<0.05$; Table 1) compared to control. Treatment K3 had the highest SGR that was significantly different to $(\mathrm{P}<0.05$; Table 1) to treatments K1, K2, K4, and control. In addition, the best FCR was also observed in treatment K3 (Table 1), indicating that probiotic bacteria combination supplemented in the feed (that was consumed by the fish) was able to reach and adhere to the digestive tract. This was in line with the probiotic population monitoring data
(Figure 4) and helped in supporting the digestive process. Treatment $\mathrm{K}+$ had the lowest SGR, which was influenced by both total feed intake and nutritional status of the fish before and after the challenge test with $S$. agalactiae N14G Rif ${ }^{\mathrm{R}}$. The low FCR that were observed in P22 Cip ${ }^{\mathrm{R}}$ and $\mathrm{L} 1 \mathrm{k} \mathrm{Tet}^{\mathrm{R}}$ probiotic combination treatments illustrated that a low feed consumption ( a specific amount of feed) can be optimally utilized so as to increase growth. Salamah et al. (2013) reported that the addition of L1k heterotrophic bacteria cells can result in a better survival rate on the host. That was in line with Sya'bani et al. (2015) who stated that the application of L1k probiotic combination is able to influence the survival rate (higher percentage) of the host. B. cereus P22, S.

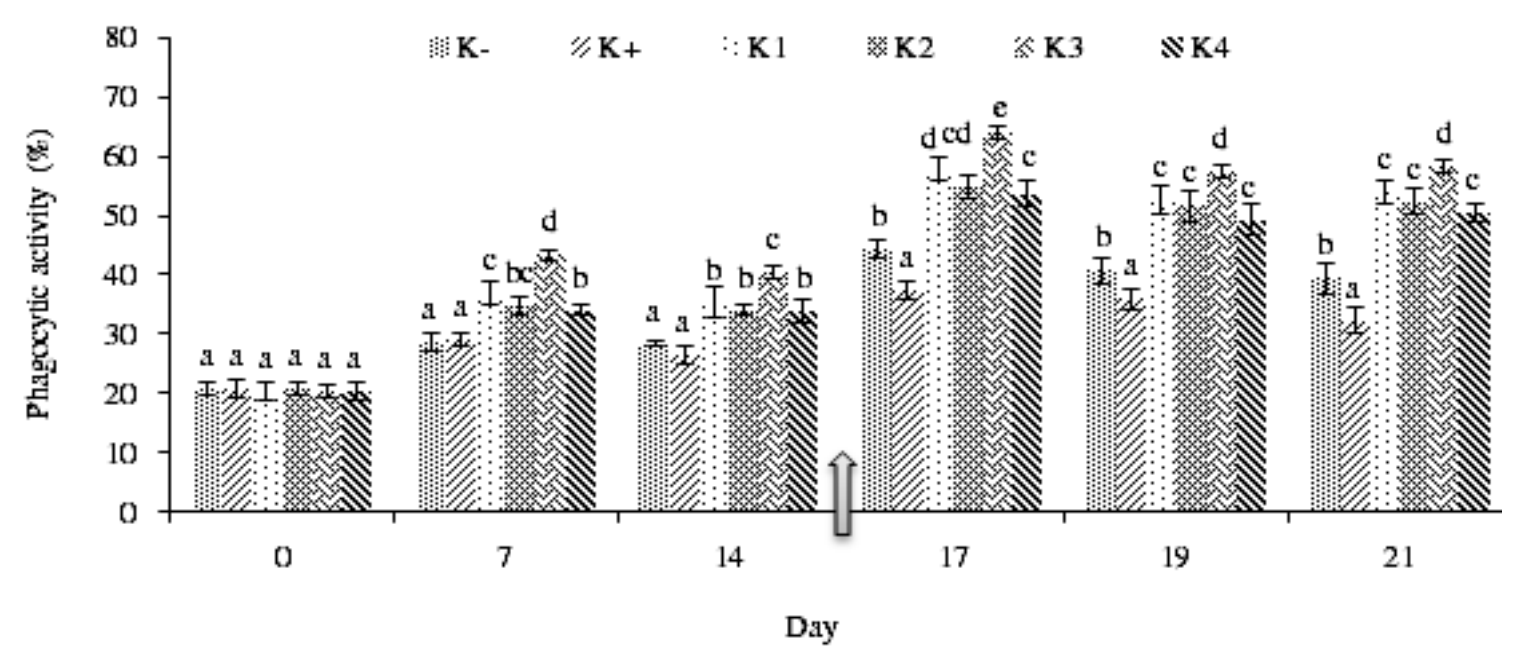

Figure 1. Phagocytic activity (PA) during the rearing period. The arrow shows the injection time of the challenge test with $S$. agalactiae N14G RifR. Different letters at the end point of the bar graph showed significant differences $(\mathrm{P}<0.05)$. Negative control without challenge test $(\mathrm{K}-)$, while positive control $(\mathrm{K}+), \mathrm{P} 22 \mathrm{CipR}$ and ND2 CefR combination (K1), ND2 CefR (K2) and L1k TetR combination (K2), P22 CipR and L1k TetR combination (K3) and P22 CipR, ND2 CefR and L1k TetR combination (K4) were subjected to challenge test.

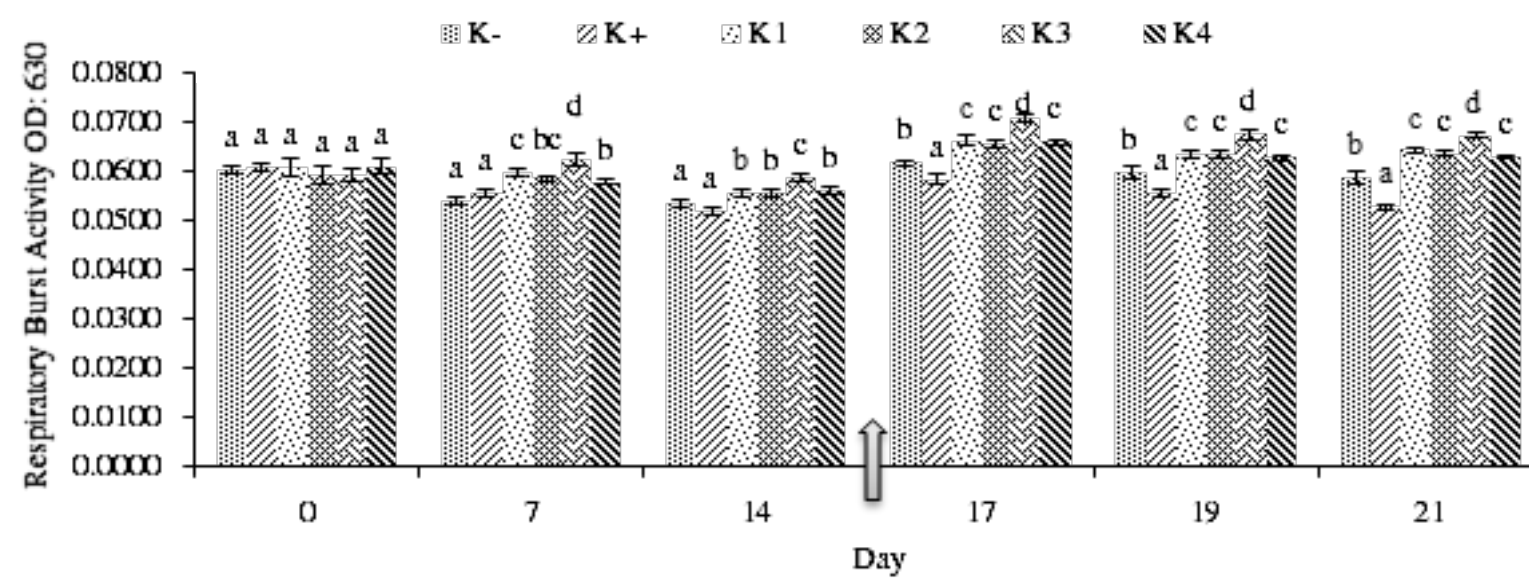

Figure 2. Respiratory burst activity (RB) during the rearing period. The arrow shows the injection time of the challenge test with $S$. agalactiae N14G RifR. Different letters at the end point of the bar graph showed significant differences $(\mathrm{P}<0.05)$. Negative control without challenge test $(\mathrm{K}-)$, while positive control $(\mathrm{K}+)$, $\mathrm{P} 22 \mathrm{CipR}$ and ND2 CefR combination (K1), ND2 CefR (K2) and L1k TetR combination (K2), P22 CipR and L1k TetR combination (K3) and P22 CipR, ND2 CefR and L1k TetR combination (K4) were subjected to challenge test. 

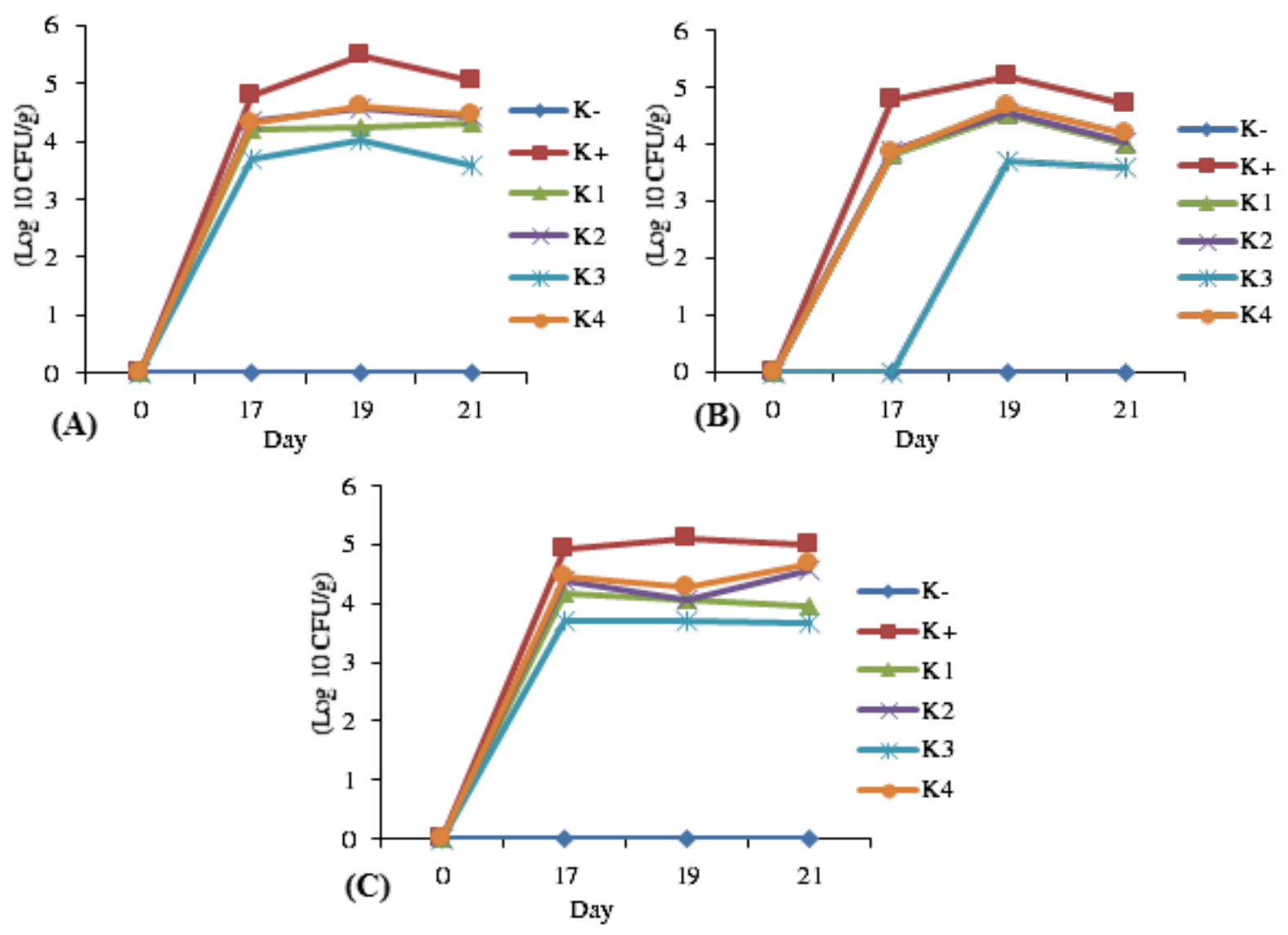

Figure 3. Monitoring of the density of S. agalactiae N14G RifR cells in the brain (A), eyes (B), and the kidney (C) $(\log 10 \mathrm{CFU} / \mathrm{g})$ of the test fish post challenge test during the rearing period. Negative control without challenge test (K-), while positive control (K+), P22 CipR and ND2 CefR combination (K1), ND2 CefR (K2) and L1k TetR combination (K2), P22 CipR and L1k TetR combination (K3) and P22 CipR, ND2 CefR and L1k TetR combination (K4) were subjected to challenge test.

lentus L1k and B. subtilis ND2 are Gram-positive bacteria and according to Buruiana et al. (2014), Gram-positive bacteria can influence enzymatic activity by increasing it.

Putra and Widanarni (2015) demonstrated that Bacillus probiotic supplemented through feed can increase amylase activity, carbohydrate digestion, and growth performance of tilapia. Fidyandini et al. (2016), stated that a combination of S. lentus L1k and B. subtilis ND2 can optimally inhibit the growth of A. hydrophila in catfish (Dumbo strain). In addition, Lallo et al. (2007, 2008), also stated that $B$. cereus can obstruct the growth of A. hydrophila. According to Bernard et al. (2013), B. cereus revealed antagonic activities against three pathogens i.e. Vibrio alginolyticus, A. hydrophila and Pseudomonas putida, while the strongest antagonistic effect was observed against $V$. alginolyticus. B. cereus is safe for usage in tilapia farming activities.

Health status of tilapia was observed based on blood profile parameters as indicators of the immune response. Treatments K1, K2, K3, and
K4 significantly influenced both PA and RB of tilapia compared to treatments $\mathrm{K}$ - and $\mathrm{K}+$. PA and RB (Figure 1 and Figure 2), in each treatment during 21 days, experienced fluctuations. The highest PA occurred on day 7 (2 days after challenge test injection), which was observed in treatment $\mathrm{K} 3$ i.e. $64.00 \pm 2.65 \%$ and this value was significantly different $(\mathrm{P}<0.05)$ compared to $\mathrm{K}+$ treatment $(37.33 \pm 1.53 \%)$. In line with the increase in PA, the respiratory burst experienced sharp increments on day 17 and treatment $\mathrm{K} 3 \mathrm{had}$ the highest $\mathrm{RB} 0.07 \pm 0.00 \mathrm{OD}$ compared to $\mathrm{K}+$ $(0.06 \pm 0.00 \mathrm{OD})$. The phagocytic index illustrates the activity of phagocytic cells in carrying out the phagocytosis process (engulfing pathogenic bacteria cells). RB occurs in Phagocytic cells that perform phagocytosis that produces anion $\left(\mathrm{H}_{2} \mathrm{O}_{2}\right)$ and super oxidate $\left(\mathrm{OH}^{-}\right)$that are highly toxic to bacteria, leading to an increase in phagocytic cells ability to destroy pathogenic bacteria (Rawling et al., 2012). The increments in both $\mathrm{PA}$ and $\mathrm{RB}$ in the present research demonstrated that the supplementation of a combination of 

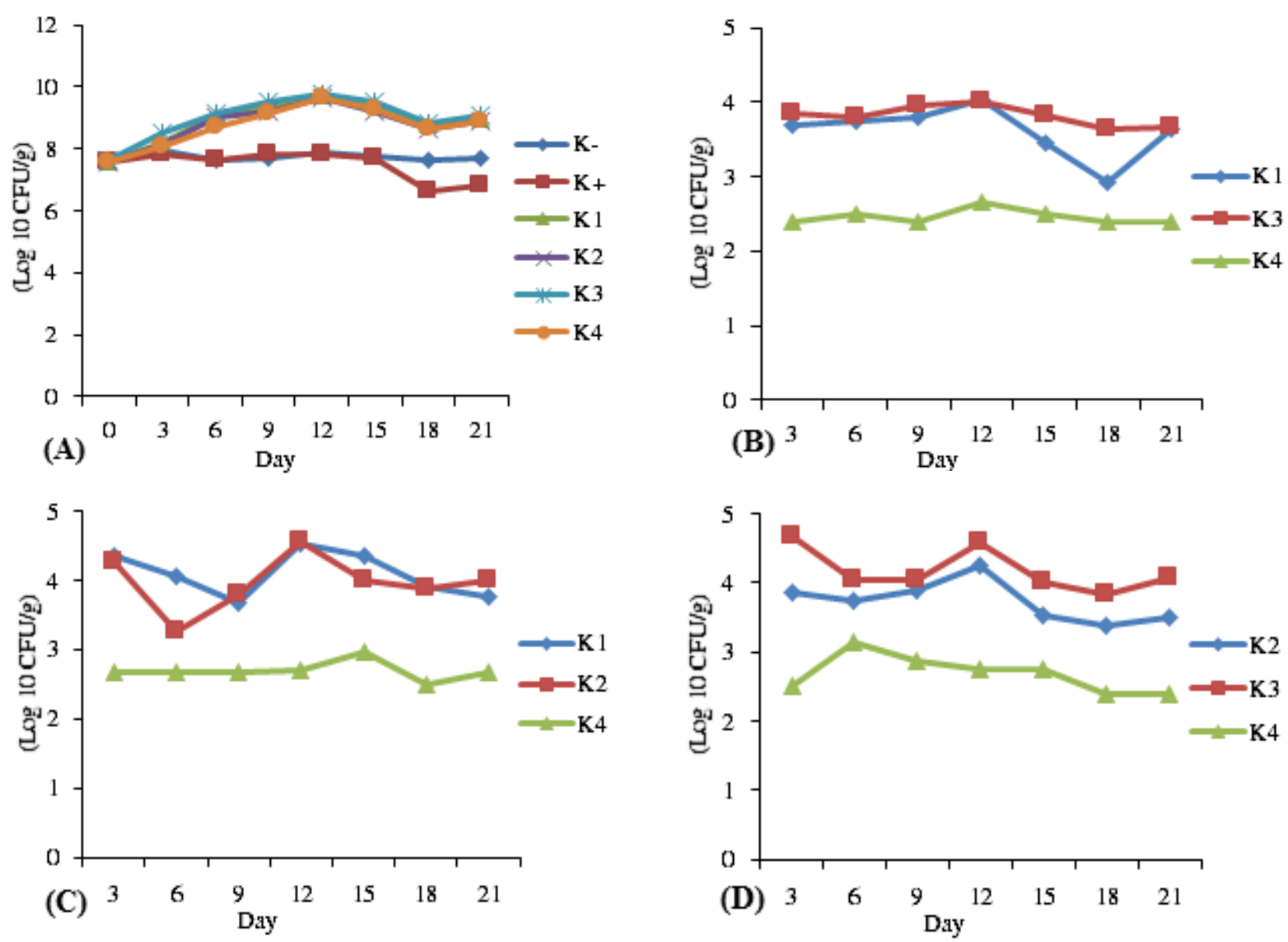

Figure 4. Monitoring of the total probiotic cell density in the intestine (A), the density of P22 CipR (B) cells, density of ND2 CefR probiotic cells (C) and density of L1k TetR (D) probiotic cells (Log 10 CFU/g) of the test fish during the rearing period. Negative control (K-) and positive control $(\mathrm{K}+)$ with multispecies probiotics, $\mathrm{P} 22$ CipR and ND2 CefR combination (K1), ND2 CefR (K2) and L1k TetR combination (K2), P22 CipR and L1k TetR combination (K3) and P22 CipR, ND2 CefR and L1k TetR combination (K4).

probiotics can enhance the immune system in order to actively stand against $S$. agalactiae N14G Rif $^{\mathrm{R}}$ pathogenic infection. According to Agung et al. (2015), changes in blood profile pictures can occur as consequences of both stress condition or presence of pathogens.

The monitoring of cell population displays the ability of the best probiotic combination to inhibit the growth of $S$. agalactiae N14G Rif ${ }^{\mathrm{R}}$. The lowest cell population density was observed in treatment $\mathrm{K} 3$ in the brain $(3.56 \pm 0.06 \mathrm{Log} 10 \mathrm{CFU} / \mathrm{g}$ ) (Figure $3 \mathrm{~A})$, the eyes $(3.59 \pm 0.03 \mathrm{Log} 10 \mathrm{CFU} / \mathrm{g}$ ) (Figure $3 \mathrm{~B})$ and the kidney $(3.70 \pm 0.17 \log 10 \mathrm{CFU} / \mathrm{g})$ (Figure 3C). In line with that, the observed total probiotic cells experienced increments during 14 days of probiotic combination supplementation (Figure 4A). meanwhile, monitoring probiotic cells P22 Cip ${ }^{\mathrm{R}}$ (Figure 4B), ND2 $\mathrm{Cef}^{\mathrm{R}}$ (Figure 4C), and L1k Tet ${ }^{R}$ (Figure 4D), revealed that the combination of probiotics, that was supplemented in the feed, can adhere to the digestive tract and play a synergic role in supporting increments in immune response, growth response and maintenance of an optimal survival. The increment and reduction in S. agalactiae N14G $\mathrm{Rif}^{\mathrm{R}}$ growth are influenced by the population of probiotics. The reduction of pathogen density in the target organs is believed to be the side effect of the increase in probiotics density in the digestive tract of the host.

Nayak (2010) stated that the application of probiotics can increase host resistance against pathogenic infection by mean of increasing the non-specific immune system of the host. Results from several types of research demonstrated that the utilization of heterogeneous probiotics in tilapia and other aquatic organisms can increase the performance of lymphocytes, granulocytes, lysozyme activities and bactericidal serum activity (Pirarat et al., 2011; Sorroza et al., 2012; Sharma et al., 2013). Fidyandini et al. (2016) stated that $S$. lentus is a non-pathogenic heterotrophic bacteria so that its supplementation is believed to be able to increase the total bacterial population. $B$. cereus produces anti-microbial substances i.e. cerein (Bizani \& Brandelli, 2002) which can 
inhibit Gram-positive pathogens (Ghanbari et al., 2009). Bacillus spp. makes antibiotic compound i.e colistin and polymixin, that are effective against Gram-negative bacteria (Amin et al., 2012). A research conducted by Navinchandran et al. (2014) revealed that extracellular enzymes that are produces by $B$. cereus as probiotics (supplemented through shrimp feed) can increase both immunology parameters and growth of the host. Brito et al. (2012) stated that the production of antimicrobial plays a role in the modulation of the immune system i.e. white blood cells so that the performance of spreading white blood cells increases the defense system from pathogenic infections.

\section{CONCLUSION}

The appropriate multispecies probiotics combination in the present study was a combination of Bacillus cereus P22 and Staphylococcus lentus L1k (that was supplemented at the optimal dose of $1 \%(\mathrm{v} / \mathrm{w}))$ that increased both growth performance and immune response of tilapia to prevent streptococcosis.

\section{REFERENCES}

Agung LA, Widanarni, Yuhana M. 2015. Application of micro-encapsulated probiotic Bacillus NP5 and prebiotic mannan oligosaccharide (MOS) to prevent streptococcosis on tilapia Oreochromis niloticus. Research Journal of Microbiology 10: 571-581.

Aly SM, Ahmed YAG, Ghareeb AAA, Mohamed MF. 2008a. Studies on Bacillus subtillis and lactobacillus acidophilus as potential probiotics, on immune response and resistance of tilapia nilotica Oreochromis niloticus to challenge infections. Fish and Shellfish Immunology 25: 128-136.

Aly SM, Mohamed MF, Jhon G. 2008b. Effect of probiotics on the survival, growth and challenge infection in tilapia nilotica Oreochromis niloticus. Aquaculture Research 39: 647-656.

Amin A, Khan MA, Ehsanullah M, Haroon U, Azam SMF, Hameed A. 2012. Production of peptide antibiotics by Bacilluc sp. GU 057 indigenously isolated from saline soil. Brazilian Journal of Microbiology 43: 1340-1346.

AndersonDP, Siwicki AK. 1995. Basichematology and serology for fish health programs. pp. 185202. In Shariff M, Authur JR, Subasinghe RP. (Ed) Diseases in Asian Aquaculture II, Fish Health Section. Philippines: Asian Fisheries Society.

Bernard VH, Nurhidayu A, Ina-Salwany MY, Abdelhadi Y. 2013. Bacillus cereus JAQ04 strain as a potential probiotic for red tilapia Oreochromis niloticus species. Asian Journal of Animal and Veterinary Advances 8: 395-400.

Bizani D, Brandelli A. 2002. Characterization of a bacteriocin produced by a newly isolated Bacillus sp. Strain 8 A. Journal of Applied Microbiology 93: 512-519.

Brito MB, Diaz JP, Quezada SM, Llorente CG, Gil A. 2012. Probiotic mechanisms of action. Annal of Nutrition and Metabolism 61: 160-174.

Buruiana CT, Profir AG, Vizireanu C. 2014. Effects of probiotic Bacillus species in aquaculture-an overview. The Annals of the University Dunarea de Jos of Galati Fascicle VI-Food Technology 38: 9-17.

Effendi MI. 2002. Biologi Perikanan. Bogor (ID): Yayasan Pustaka Nusantara.

Febrianti D, Yuhana M, Widanarni. 2016. Dietary symbiotic microcapsule influence the immune responses, growth performance and microbial populations to White Spot Syndrome Virus in pacific white shrimp Litopenaeus vannamei. Journal of Fisheries and Aquatic Science 11: $28-42$.

Fidyandini HP, Yuhana M, Lusiastuti AM. 2016. Addition of multispecies probiotics in the culture medium of african catfish to prevent the motile aeromonads septicemia disease. Jurnal Veteriner 17: 440-448.

Filho CI, Muller EE, Giardano LGP, Bracarense APFRL. 2009. Histological findings of experimental Streptococcus agalactiae infection in Nile tilapias Oreochromis niloticus. Brazilian Journal of Veterinary Pathology 2: 12-15.

Flores ML. 2011. The use of probiotic in aquaculture: an overview. International Research Journal of Microbiology 2: 471-478.

Gardenia L, Isti K, Yani A. 2011. Natural disease outbreak: diagnosis of Streptococcus agalactiae'sinfection from tilapia Oreochromis niloticus tissues using polymerase chain reaction. Jurnal Perikanan Universitas Gajah Mada 13: 22-26.

Ghanbari M, Rezaei M, Soltani M, Shah-Hosseini 
GH. 2009. Production of bacteriocin by a novel Bacillus sp. strain RF 140, an intestinal bacterium of caspian frisian roach Rutilus frisii kutum. Iranian Journal of Veterinary Research, Shiraz University 10: 267-272.

Haditomo AHC, Lusiastuti AM, Widanarni. 2016. The study of Bacillus firmus as probiotic candidate in supressing Aeromonas hydrophila in culture media. Jurnal Saintek Perikanan 11: $111-114$.

Hardi EH, Sukenda, Harris E, Lusiastuti AM. 2011. Characterization and phatogenicity of $\beta$ and non haemolytic Streptococcus agalactiae in cultured Nile tilapia. Jurnal Veteriner 12: 152-164.

Hernandez E, Figueroa J, Ireguei C. 2009. Streptococcosis on Red Tilapia, Oreochromis $s p$., farm: a case study. Journal of Fish Disease 32: 247-257.

Huisman EA. 1987. Principles of Fish Production. Departement of Fish Culture and Fisheries, Netherland (NL): Wageningen Agricultural University.

Klesius PH, Shoemaker CA, Evans JJ. 2008. Streptococcus: A worldwide fish health problem. $8^{\text {th }}$ International symposium on tilapia in aquaculture. Cairo. Agricultural Research Service 1: 83-107.

Lallo R, Ramchuran S, Ramduth D, Gorgens J, Garnider N. 2007. Isolation and selection of Bacillus spp. as potential biological agents for enchancement or water quality in culture of ornamental fish. Journal of Applied Microbiology 103: 1471-1479.

Lallo R, Maharajh D, Gorgens J, Garnider N. 2008. Functionality of a Bacillus cereus biological agent in response to physiological variables encountered in aquaculture. Applied Microbiology and Biotechnology 79: 111-118.

Li YW, Liu L, Huang PR, Fang W, Lou ZP, Peng HL, Wang YX, Li AX. 2014. Chronic streptococcosis in Nile tilapia, Oreochromis niloticus (L.), caused by Streptococcus agalactiae. Journal of Fish Disease 37: 757-763.

Madigan MT, Martinko JM, Stahl DA, Clark DP. 2012. Brock Biology of Microorganisms. $13^{\text {th }}$ ed. San Francisco (USA): Pearson Education Inc.

Navinchandran M, Iyapparaj P, Moovendhan S, Prakash S, Immanuel G, Palavesam A. 2014. Influence of probiotic bacterium Bacillus cereus isolated from the gut of wild shrimp
Penaeus monodon in turn as a potent growth promoter and immune enhancer in P. monodon. Fish and Shellfish Immunology 36: 38-45.

Nayak, SK. 2010. Probiotic and immunity : A fish perspective. Fish and Shellfish Immunology 29: 1-14.

Nijah M, Aqilah NI, Lee KL, Bariyyah KZ, Mithun S, Jalal KLA, Shaharom-Harisson F, Nadirah M. 2012. Massive mortality associated with Streptococcus agalactiae infection in cage cultured Red Hybrid tilapia Oreochromis niloticus in Como River, Kenyir Lake, Malaysia. Journal of Biological Sciences 12: 438-442.

Pirarat N, Pinpimai K, Endo M, Katagiri T, Ponpornpisit A, Chansue N, Maita M. 2011. Modulation of intestinal morphology and immunity in Nile tilapia Oreochromis niloticus by Lactobacillus rhamnosus GG. Research in Veterinary Science 91: 92-97.

Putra AN, Widanarni. 2015. Screening of amylolytic bacteria as candidates of probiotik in tilapia Oreochromis sp. Reasearch Journal of Microbiology 10: 1-13.

Rawling MD, Merrifield DL, Snellgrove DL, Kuhlwein H, Adams A, Davies SJ. 2012. Haemato-immunological and growth response of mirror carp Cyprinus carpio feed a tropical earthworm meal in experimental diets. Fish and Shellfish Immunology 32: 1002-1007.

Salamah, Utomo NBP, Yuhana M, Widanarni. 2015. Growth performance of catfish, Clarias gariepinus Burchel 1822, cultured in bioflocbased system with addition of the heterotrophic bacteria cells. Jurnal Iktiologi Indonesia 15: 155-164.

Sanders ME. 2008. Probiotics: definition, sources, selection and uses. Clinical Infectious Disease. 46: S58-61.

Setiawati JE, Tarsim, Adiputra, Hudaidah S. 2013. Pengaruh penambahan probiotik pada pakan dengan dosis berbeda terhadap pertumbuhan, kelulushidupan, efisiensi pakan dan retensi protein ikan patin Pangasius hypopthalmus. e-Jurnal Rekayasa dan Teknologi Budidaya Perairan 1: 151-162.

Sharma P, Ram C, Sihag CR, Gahlawat SK. 2013. Relative efficacy of two probiotics in controlling the Epizootic Ulcerative Syndrome disease in migral Cirrhinus mrigala Ham. Journal of Fisheries and Aquatic Science 8: 305-322.

Singh SK, Tiwari VK, Chadha NK, Prakash C, Sukham M, Das P, Mandal SC, Chanu 
TI. 2013. Effect of Bacillus circulans and fructoologosaccharide supplementation on growth and haemato-immunological function of Labeo rohita (Hamilton, 1822) fingerlings exposed to sub-lethal nitrite stress. The Israel Journal of Aquaculture 64: 1-11.

Sorroza L, Padilla D, Acosta F, Roman L, Grasso V, Vega J, Real F. 2012. Characterization of probiotic strain Vagococcus fluvialis in the protection of European sea bass Dicentrarchus labrax against vibriosis by Vibrio anguillarum. Veterinary Microbiology 155: 369-373.

Standar Nasional Indonesia (SNI). 2009. Produksi ikan nila Oreochromis niloticus Bleeker kelas pembesaran di kolam air tenang. Badan Strandardisasi Nasional. SNI 7550: 2009.

Sya'bani N, Yustiatuti A, Rustikawati I, Lusiastuti AM. 2015. Frekuensi penambahan probiotik Bacillus sp. dan Staphylococcus sp. pada media pemeliharaan benih ikan lele dumbo Clarias gariepinus untuk ketahanan terhadap Aeromonas hydrophila. Jurnal Perikanan Kelautan 6: 135-140.

Takeuchi 1988. Laboratory Work-Chemical
Evaluation of Dietary Nutriens. P.179 233, in Watanabe (Ed) Fish Nutrition and Mariculture. Japan (JP): Kanagawa International Fisheries Training. Japan International Cooperation Agency.

Taukhid, Lusiastuti AM, Sumiati T. 2014. Application of Streptococcus agalactiae vaccine to prevent streptococcosis on tilapia culture, Oreochromis niloticus. Berita Biologi 13: 245-253.

Wang M, Liu G, Lu M, Ke X, Liu Z, Gao F, Cao J, Zhu H, Yi M, Yu D. 2016. Effect of Bacillus cereus as a water or feed additive on the gut microbiota and immunological parameters of Nile tilapia. Aquaculture Research 48: 31633173.

Widyaningsih EN. 2011. Peran probiotik untuk kesehatan. Jurnal Kesehatan 4: 14-20.

Ye X, Li J, Lu MX, Deng GC, Jiang XY, Tian YY, Quan YC, Jian Q. 2011. Identification and molecular typing of Streptococcus agalactiae isolated from pond cultured tilapia in China. Fisheries Science 77: 623-632. 